Historic, archived document

Do not assume content reflects current scientific knowledge, policies, or practices. 
United States Department of Agriculture

Forest Service

Pacific Northwest Research Station

Research Note PNW-RN-500

February 1991

\title{
Fertilization and Spacing Effects on Growth of Planted Ponderosa Pine.
}

\author{
P.H. Cochran, R.P. Newman, and James-W. Barrett. 1991
}

Fertilizer placed in the planting hole increased height growth of ponderosa pine (Pinus ponderosa Dougl. ex Laws.) early in the life of the plantation. Later broadcast applications of fertilizer may have had little effect on growth. Wider spacings produced larger trees but less volume per acre than narrower spacings after average tree height exceeded 7 feet. Fertilization produced larger trees and more volume per acre at each spacing.

Keywords: Nutrient availability, indirect fertilization effects, root development.

Banding fertilizer beside the row and below the surface is often more efficient than broadcast application for cultivated annual farm crops. Farm crops have rapidly developing root systems that use a large volume of soil, and competing vegetation is greatly reduced or eliminated. In contrast, tree seedlings use a smaller volume of soil the first year after planting, and competing vegetation usually surrounds the planted trees. Broadcast application of fertilizer to newly planted seedlings may increase growth of competing vegetation, and only a small fraction of the fertilizer comes in contact with the slowly expanding roots of the tree seedlings. Placement of the fertilizer in or near the planting hole (the forestry equivalent of banding) increases the probability of uptake by the tree seedlings, provided the tree roots are not damaged. Because trees are long-term crops, slow-release fertilizers may be more efficient than those used in standard agricultural operations.

Austin and Strand (1960) reported increased growth and good survival of Douglas-fir (Pseudotsuga menziesii (Mirb.) Franco) seedlings near the Oregon coast when fertilizer pellets contaiıing slowly available phosphorus $(P)$, and nitrogen $(N)$ were placed in the planting hole. More recently, briquets of slowly available $N, P$, and potassium $(\mathrm{K})$ with calcium $(\mathrm{Ca})$, magnesium $(\mathrm{Mg})$, copper $(\mathrm{Cu})$, iron $(\mathrm{Fe})$, manganese $(\mathrm{Mn})$, and zinc $(\mathrm{Zn})$ placed in the planting hole seemed to increase first year Douglas-fir seedling growth without decreasing survival in southwestern Oregon (Atalla 1987). Another study in southwestern Oregon showed that fertilizer placed 6 inches deep and 3 inches downslope from the Douglas-fir seedlings produced large increases in growth for 2 years after planting. The best response in that exploratory study was from 20-10-10-10 plus Ca (Hass 1987). Porada (1987) also

P.H. COCHRAN is a soil scientist, R.P. NEWMAN is a forestry technician, and JAMES $W$. BARRETT is a research forester (retired), Forestry Sciences Laboratory, 1027 N.W.

Trenton Avenue, Bend, OR 97701 


\section{Methods of Study}

Study Area

Treatments and Related Operations reported increased growth rates for Douglas-fir and western hemlock (Tsuga heterophylla (Raf.) Sarg.) in Washington after placement of triple super phosphate and ammonium nitrate 6 inches from the seedling base and 10 inches deep.

Often the most desirable spacing for plantations is the spacing that will allow an economical commercial thinning in the shortest time. Fertilizer, if properly placed, could reduce the time necessary for trees in plantations to reach commercial size for a given spacing. Control of competing vegetation would increase both water and nutrient availability to the tree seedlings. This study was conducted to determine the influence of fertilization and spacing on the growth of ponderosa pine (Pinus ponderosa Dougl. ex Laws.) planted on a common soil in central Oregon in the absence of the usual competing shrub species, bitterbush (Purshia tridentata (Pursh) DC.), manzanita (Arctostaphylos uva-ursi (L.) Spreng.) and snowbrush (Ceanothus velutinus Dougl. ex Hook).

The study is located about 35 miles southwest of Bend, Oregon, in a transition zone between ponderosa pine/bitterbrush-manzanita/sedge (Carex pensylvanica Lam.) and ponderosa pine/bitterbrush-snowbrush/sedge plant communities (Volland 1985). The study area has a slight southern aspect. The elevation is 4,300 feet above sea level, and annual precipitation averages 24 inches per year. Summers are dry, and about 85 percent of the precipitation falls between October 1 and April 30 as snow. Radiation frost can occur any night during the growing season. Site index is 78 feet (Meyer 1961). The soil is a Typic Cryorthent developing on 28 inches of dacite pumice and ash from Mount Mazama over older volcanic ash containing cinders and basalt fragments. The A1 horizon is 2 inches thick, the AC horizon has an average thickness of 19 inches, and the $C$ horizon is about 50 percent mixed with material from the $A C$ horizon and the older buried soil. The area was logged of overstory trees, and competing bitterbrush, manzanita, and snowbrush plants were removed before the study was installed. The A1 horizon was mixed with the upper portion of the AC horizon during these activities.

Five spacing treatments were studied $(6 \times 6,9 \times 9,12 \times 12,15 \times 15$, and $18 \times 18$ feet). Ponderosa pine seedlings (3-0) were planted in auger holes in April 1966. Seed source was 11 miles south of the study area at the same elevation. For the fertilized treatment, 113 grams of magnesium ammonium phosphate (M.A.P.), ( 9 grams of N, 20 grams of $P$, and 16 grams of $\mathrm{Mg}$ ) were placed in the bottom of the auger hole, covered with 2 to 5 inches of soil, and then the tree was planted. The M.A.P. used in this study was composed of different sized granules to provide for nutrient release over an extended time. Similar M.A.P. performed well in another study with similar soil conditions (Barrett and Youngberg 1970). Sulfur (S) as gypsum was to be placed in the planting hole, but gypsum was not available during planting. Therefore, 2 weeks after planting, 57 grams of ammonium sulfate (12 grams of $N$ and 14 grams of S) were broadcast in a circle 2 feet in diameter around each tree in the fertilized treatments. 
Plot Layout and Study Design

Tree Measurements
In the first few years after installation of the study, root rot (Armillaria ostoyae (Romag.) Herink.) in the general area seemed severe-some fertilized and nonfertilized trees died, and it seemed the entire study might be lost. After initial fertilization produced some response in height growth for the first three growing seasons (Barrett and Youngberg 1970), additional fertilization was done to see if the trees would become vigorous enough to overcome the root rot attacks. Additional fertilizer was applied in fall 1971 and again in fall 1973. At both times, 270 pounds per acre of $\mathrm{N}$ (in the form of urea) was broadcast over the half plots initially chosen for fertilizer treatments.

Bitterbrush, manzanita, and snowbrush, which reinvaded the area after planting, were effectively controlled with two applications of 2-4-5 T. This herbicide was applied in 1969 and 1973.

Each spacing was replicated twice. Rectangular plots were used, and one-half of each plot was randomly chosen for the fertilizer treatment. Plots differ in size. Each half plot consisted of 12 trees that were measured plus a surrounding isolation strip containing rows of similarly treated trees. Isolation strips contained two rows of trees for the 15- and 18-foot spacings and three rows of trees for the 6-, 9- and 12-foot spacings. Spacings were randomly assigned to tentative plots on a map and then the plots were established in the field. Before planting, the half plot to receive fertilizer was chosen by flipping a coin.

The design of the study is a completely randomized split plot with five spacing treatments (replicated twice) for whole plots and fertilization treatments for half plots. With measurements for more than one time period, the design becomes a split plot in space and time.

From 1967 to 1974, tree heights were measured annually after the growing season on all plots. In fall 1974 , all trees were taller than 4.5 feet, so diameters at breast height were also measured. Heights and diameters were again measured in fall 1980 and 1984. Cubic foot volumes inside bark at these three separate times were determined for each tree with an equation using a form factor that is a function of diameter and height (DeMars and Barrett 1987).

Volume, basal area, quadratic mean diameter, and average height for each half plot were calculated from the inventories taken in 1974, 1980, and 1984. Gross periodic annual increments were then obtained for these two periods (the 1975-80 and 1981-84 growing seasons) by subtracting initial values from the final values for each period and dividing this quantity by the number of growing seasons (six for period 1 and four for period 2). These values are gross values because none of the measurement trees for each half plot died after 1974. 
Two separate analyses of variance were performed with the annual height increments that occurred before all the trees were 4.5 feet high. The hypotheses tested in each analysis were that fertilization and spacing did not affect height growth and that there was no difference in height growth with individual growing seasons. The first analysis was for the 1967 through 1971 growing seasons before urea was first broadcast over the fertilized half plots. The second analysis was for the 1967 through 1974 growing seasons, a period that included the two applications of urea to the fertilized half plots. Missing values (which occurred when two ha!f plots were lost to root rot) were estimated as outlined by Steel and Torrie (1960).

Analyses of variance with split plots in space and time were also performed (SAS Institute 1982) for periodic annual increments from the two periods after all the trees reached heights exceeding 4.5 fert. These analyses tested the hypothesis that fertilization, spacing, and growing period did not influence periodic annual increments. Analyses of variance were also performed for average height, mean diameter, basal area, and volume found on the various treatment combinations in fall 1974, 1980, and 1984 to test the hypothesis that these parameters were not influenced by spacing or fertilization.

Analyses of covariance with split plots in space and time were also performed (SAS institute 1982). Average height, quadratic mean diameter, basal area, and volume at the start of each period were used as covariates for the corresponding periodic annual increments. These analyses were performed to test the hypothesis that after 1975, growth rates were related to tree size and density and not to increased tree nutrition. These analyses of covariance were not part of the original study plan.

Results

Mortality

Height Growth
Two half plots were completely lost to armillaria root rot in 1966. One was a fertilized half plot with a $6-\times 6$-foot spacing and the other was an unfertilized half plot with a $12-\times 12$-foot spacing. Of the 18 remaining half plots, 13 lost no trees, 4 lost one tree, and 1 lost 2 trees. There was no apparent relation between spacing, fertilizer treatment, and mortality. After 1973 , the severity of armillaria root rot in the general area seemed to subside.

Spacing alone did not affect the rate of height growth for the 1967-74 growing seasons. Height growth, however, began to increase more at wider spacings toward the end of this period (table 1). Height growth increments averaged over all spacings increased for the second through sixth growing seasons after planting, decreased for the seventh growing season (just after the second fertilization), and then increased for the next two growing seasons (fig. 1). Fertilization increased height growth in each spacing. By the end of 1974, nine growing seasons after planting, the trees were about the same height for all spacings, but the fertilized trees were taller (fig. 2).

For both the 1975-80 and 1981-84 periods, the wider spacings exhibited greater height growth (tables 2 and 3). Height growth was greater for the 1981-84 period at the narrower spacings, and height growth for the fertilized treatments was greater for both periods at all but the widest spacing. By fall 1984, the fertilized trees in all but the widest spacing treatments continued to be the tallest, and the height of the trees increased with the wider spacings (fig. 2, table 4). 
Table 1-Levels of probability for significance in the analysis of variance of annual height growth for the 1967-71 and the 1967-74 growing seasons

\begin{tabular}{lcr}
\hline & \multicolumn{2}{c}{ Growing seasons } \\
\cline { 2 - 3 } Variables & $1967-71$ & $1967-74$ \\
\hline Spacing & 0.41 & 0.26 \\
Year & $<0.01$ & $<0.01$ \\
Year $\times$ spacing & .76 & .02 \\
Fertilizer & & \\
Fertilizer $\times$ spacing & .05 & .05 \\
Fertilizer $\times$ year & .93 & .83 \\
Fertilizer $\times$ year $\times$ spacing & .30 & .54 \\
\hline
\end{tabular}

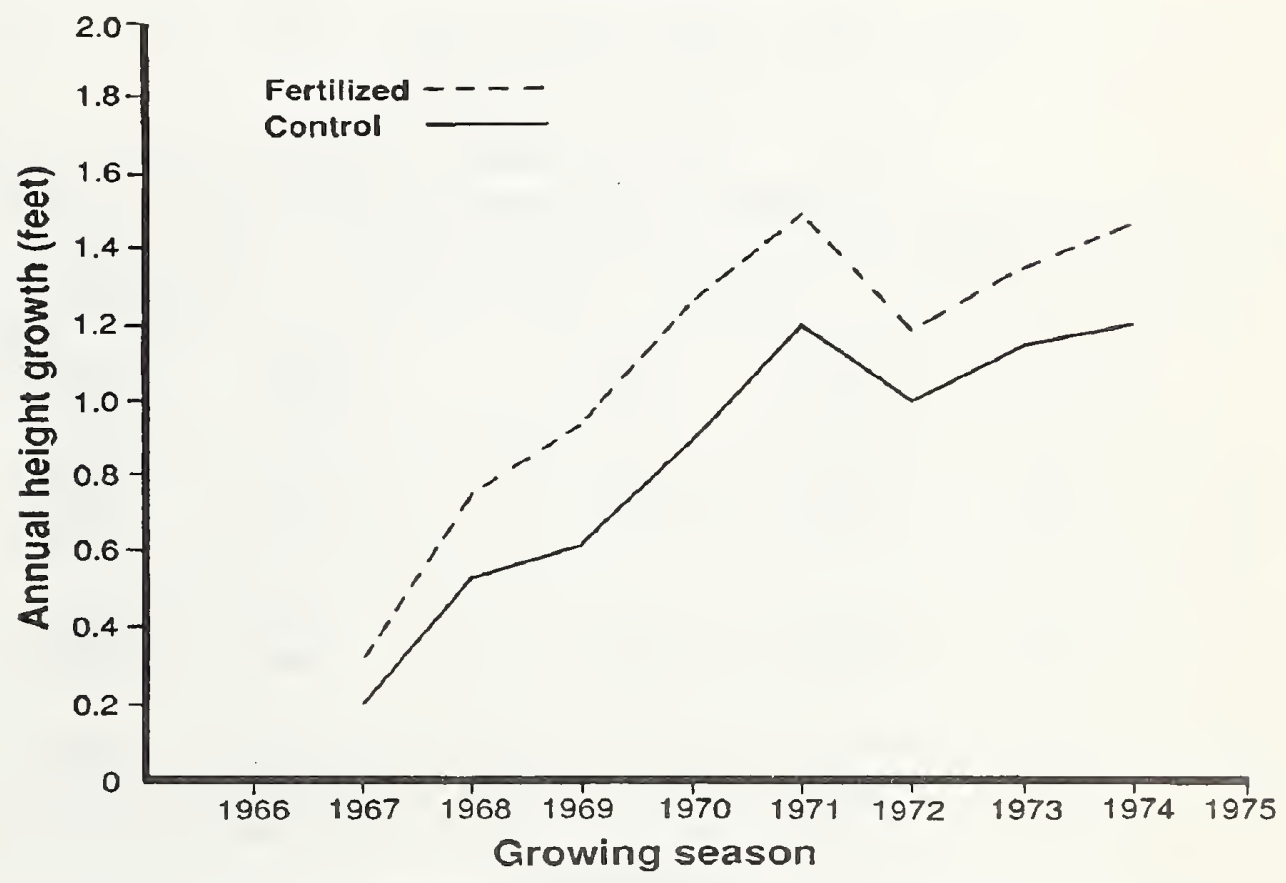

Figure 1-Annual increments for average heights during the 1967-74 growing seasons. Additional fertilization took place in fall 1971 and 1973, before the 1972 and 1974 growing seasons. These average increments do not include estimated values for two missing half plots used in the analyses of variance. 


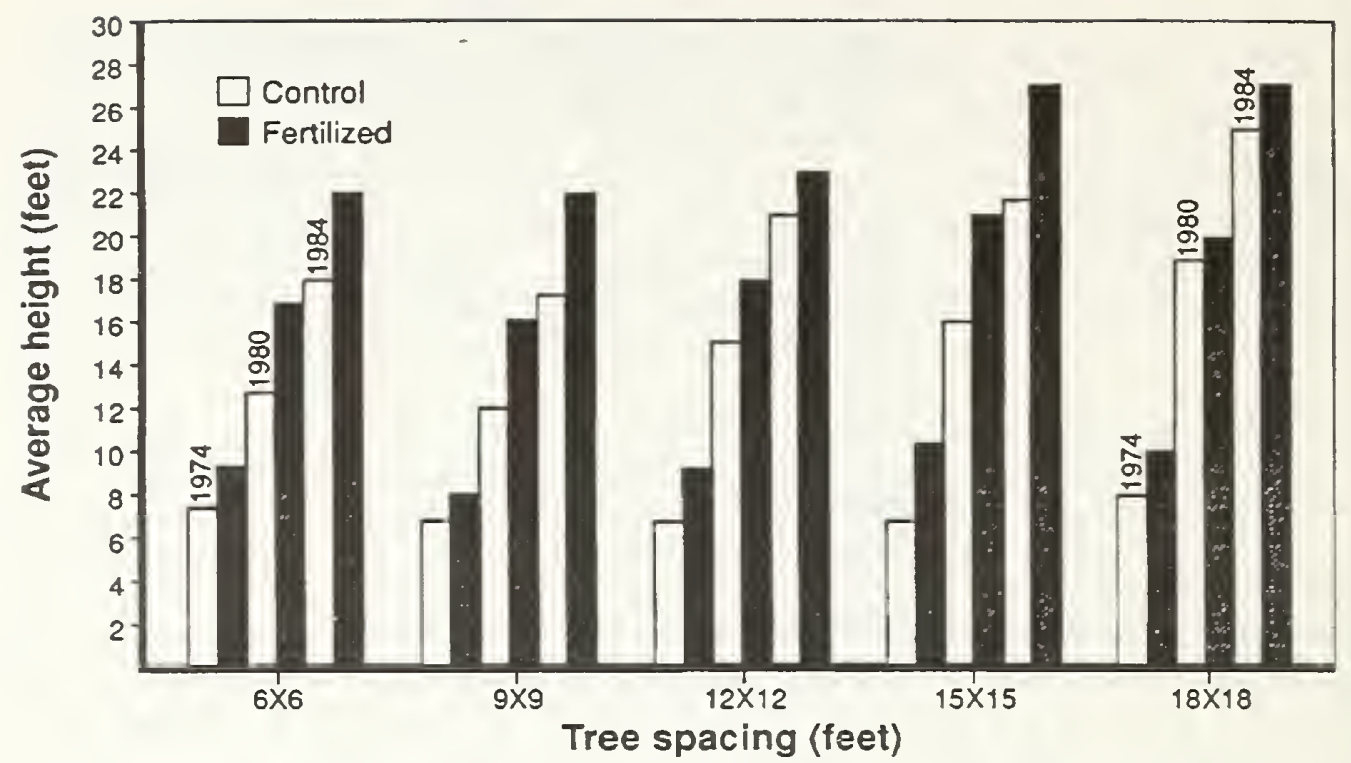

Figure 2-Average heights for the surviving spacing-fertilizer combinations in fall 1974, 1980, and 1984. Trees were planted in spring 1966.

Table 2-Levels of probability for significance in the analyses of variance for the periodic annual increments during $1975-80$ and $1981-84$

\begin{tabular}{lcccc}
\hline & \multicolumn{4}{c}{ Periodic annual increments } \\
\cline { 2 - 5 } Variables & Height $^{a}$ & Diameter $^{b}$ & Basal area & Volume \\
\hline Spacing & $<0.01$ & $<0.01$ & 0.07 & 0.12 \\
Period & $<.01$ & .01 & .01 & $<.01$ \\
Spacing $\times$ period & $<.01$ & .56 & .02 & .85 \\
& & & & .02 \\
Fertilizer & .04 & .20 & .32 & .01 \\
Fertilizer $\times$ spacing & .14 & .27 & .04 & .16 \\
Fertilizer $\times$ period & .19 & .32 & .16 & .44 \\
Fertilizer $\times$ period $\times$ spacing & .04 & .42 & .16 & \\
\hline
\end{tabular}

a Height is average height.

Diameter is the quadratic mean diameter. 
Table 3-Average periodic annual increments for the control and fertilized half plots for each spacing treatment during the 1975-80 growing seasons and the 1981-84 growing seasons

\begin{tabular}{|c|c|c|c|c|c|c|c|c|c|c|c|}
\hline \multirow[b]{3}{*}{ Parameter } & \multirow[b]{3}{*}{ Period } & \multicolumn{10}{|c|}{ Spacing treatment (feet) } \\
\hline & & \multicolumn{2}{|c|}{$6 \times 6$} & \multicolumn{2}{|c|}{$9 \times 9$} & \multicolumn{2}{|c|}{$12 \times 12$} & \multicolumn{2}{|c|}{$15 \times 15$} & \multicolumn{2}{|c|}{$18 \times 18$} \\
\hline & & $F^{a}$ & $\mathrm{C}^{a}$ & $F$ & C & $F$ & $\mathrm{C}$ & $\mathrm{F}$ & C & $\mathrm{F}$ & C \\
\hline $\begin{array}{l}\text { Mean diameter } \\
\text { increment (in/yr) }\end{array}$ & $\begin{array}{l}1975-80 \\
1981-84\end{array}$ & $\begin{array}{r}0.3 \\
.2\end{array}$ & $\begin{array}{r}0.3 \\
.3\end{array}$ & $\begin{array}{r}0.4 \\
.3\end{array}$ & $\begin{array}{r}0.4 \\
.3\end{array}$ & $\begin{array}{r}0.5 \\
.4\end{array}$ & $\begin{array}{r}0.5 \\
.4\end{array}$ & $\begin{array}{r}0.6 \\
.5\end{array}$ & $\begin{array}{r}0.6 \\
.5\end{array}$ & $\begin{array}{r}0.6 \\
.6\end{array}$ & $\begin{array}{r}0.6 \\
.6\end{array}$ \\
\hline $\begin{array}{l}\text { Average height } \\
\text { increment (ft/yr) }\end{array}$ & $\begin{array}{l}1975-80 \\
1981-84\end{array}$ & $\begin{array}{l}1.1 \\
1.4\end{array}$ & $\begin{array}{l}0.9 \\
1.2\end{array}$ & $\begin{array}{l}1.3 \\
1.6\end{array}$ & $\begin{array}{l}1.0 \\
1.2\end{array}$ & $\begin{array}{l}1.4 \\
1.5\end{array}$ & $\begin{array}{l}1.3 \\
1.4\end{array}$ & $\begin{array}{l}1.8 \\
1.6\end{array}$ & $\begin{array}{l}1.4 \\
1.5\end{array}$ & $\begin{array}{l}1.6 \\
1.6\end{array}$ & $\begin{array}{l}1.6 \\
1.7\end{array}$ \\
\hline $\begin{array}{c}\text { Basal area increment } \\
\left(\mathrm{ft}^{2} . \mathrm{acre}^{-1} 1 . \mathrm{yr}^{-1} 1\right)\end{array}$ & $\begin{array}{l}1975-80 \\
1981-84\end{array}$ & $\begin{array}{l}13.5 \\
12.9\end{array}$ & $\begin{array}{l}8.6 \\
9.9\end{array}$ & $\begin{array}{l}7.7 \\
9.5\end{array}$ & $\begin{array}{l}4.7 \\
7.6\end{array}$ & $\begin{array}{l}5.8 \\
7.2\end{array}$ & $\begin{array}{l}4.5 \\
6.8\end{array}$ & $\begin{array}{l}5.4 \\
7.6\end{array}$ & $\begin{array}{l}3.8 \\
5.9\end{array}$ & $\begin{array}{l}4.2 \\
6.4\end{array}$ & $\begin{array}{l}3.6 \\
5.8\end{array}$ \\
\hline $\begin{array}{l}\text { Volume increment } \\
\left(\mathrm{ft}^{3} . \mathrm{acre}^{-1} 1 . \mathrm{yr}^{-1} 1\right)\end{array}$ & $\begin{array}{l}1975-80 \\
1981-84\end{array}$ & $\begin{array}{l}110.2 \\
157.8\end{array}$ & $\begin{array}{l}63.2 \\
97.0\end{array}$ & $\begin{array}{r}58.3 \\
105.6\end{array}$ & $\begin{array}{l}31.7 \\
67.0\end{array}$ & $\begin{array}{l}47.1 \\
78.8\end{array}$ & $\begin{array}{l}32.4 \\
65.9\end{array}$ & $\begin{array}{l}48.2 \\
92.2\end{array}$ & $\begin{array}{l}29.5 \\
61.0\end{array}$ & $\begin{array}{l}35.4 \\
76.45\end{array}$ & $\begin{array}{l}29.7 \\
66.2\end{array}$ \\
\hline
\end{tabular}

${ }^{a} \mathrm{~F}$ indicates fertilization; $\mathrm{C}$ is control.

Table 4-Levels of probability for significance in the analyses of variance for average height, quadratic mean diameter, basal area (BA) per acre, and volume (V) per acre occurring on the different treatments in fall 1974, 1980, and 1984

\begin{tabular}{lcccc}
\hline Variables & Height & Diameter & BAacre $^{a}$ & V/acre $^{b}$ \\
\hline Spacing & 0.01 & $<0.01$ & 0.01 & 0.03 \\
Year & $<.01$ & $<.01$ & $<.01$ & $<.01$ \\
Spacing $\times$ year & $<.01$ & $<.01$ & .03 & .09 \\
Fertilizer & .02 & .02 & $<.01$ & $<.01$ \\
Fertilizer $\times$ spacing & .61 & .71 & .16 & .19 \\
Fertilizer $\times$ year & $<.01$ & .19 & $<.01$ & $<.01$ \\
Fertilizer $\times$ year $\times$ spacing & .06 & .15 & .20 & .21 \\
\hline
\end{tabular}

BA is average basal area.

${ }^{b} \mathrm{~V}$ is average volume.

At the start of 1975, the fertilized treatments had larger diameters for each spacing, but differences among spacings were minimal (fig. 3, table 4). Diameter growth increased with wider spacings and was greater for the $1975-80$ period than for the 1981-84 period (tables 2 and 3). Fertilization did not influence diameter growth during either period. By fall 1984, the largest diameter trees continued to be in the widest spacings, and fertilized plots still had larger diameters for each spacing (fig. 3, table 4). For both height and diameter growth, spacing began to make a difference when the average height ranged from 7 to 10 feet (figs. 2 and 3). 


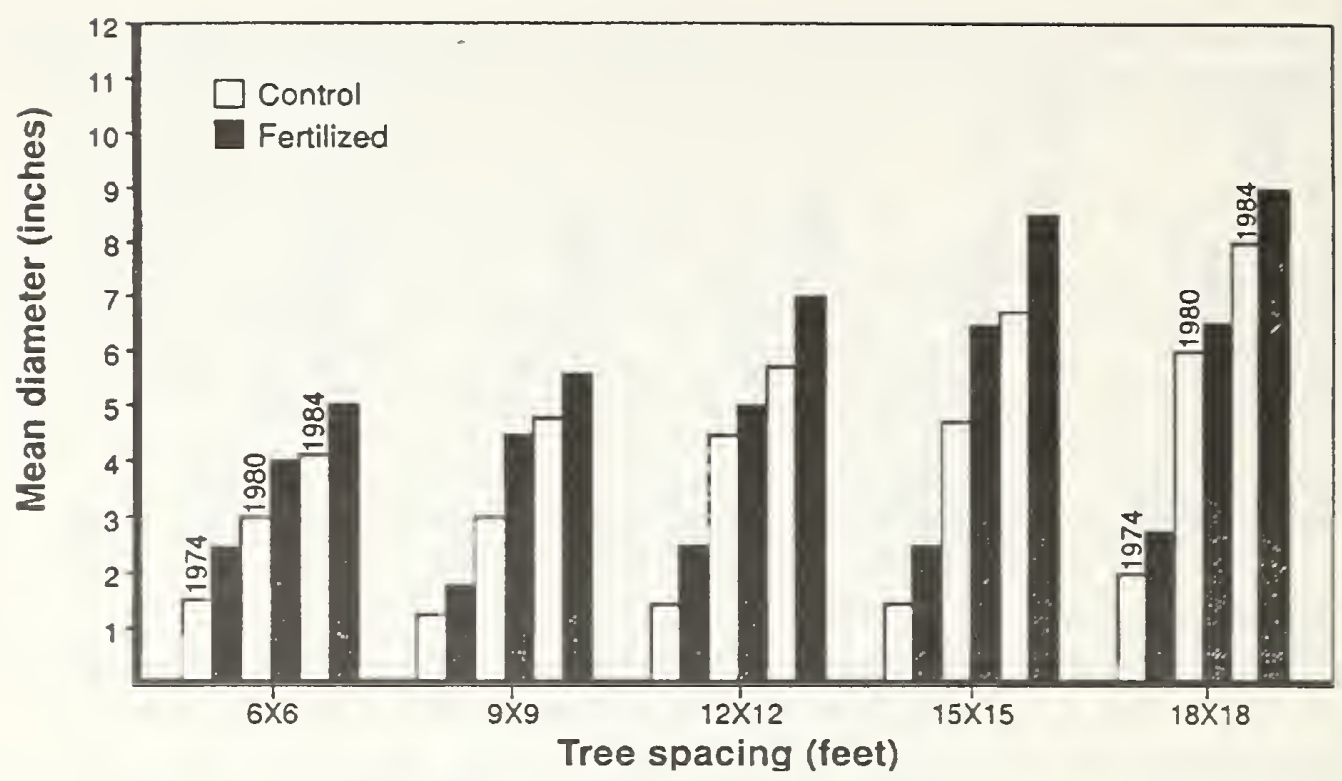

Figure 3-Quadratic mean diameters for the surviving spacing-fertilizer combinations in fall 1974, 1980, and 1984 .

Table 5-Average basal area and volume for the fertilized and control half plots at the end of the growlng season in 1974, 1980, and 1984

\begin{tabular}{|c|c|c|c|c|c|c|c|c|c|c|}
\hline \multirow[b]{3}{*}{ Parameter } & \multicolumn{10}{|c|}{ Spacing treatment (feet) } \\
\hline & \multicolumn{2}{|c|}{$6 \times 6$} & \multicolumn{2}{|c|}{$9 \times 9$} & \multicolumn{2}{|c|}{$12 \times 12$} & \multicolumn{2}{|c|}{$15 \times 15$} & \multicolumn{2}{|c|}{$18 \times 18$} \\
\hline & $\mathrm{F}^{\mathrm{a}}$ & $c^{a}$ & $F$ & $\mathrm{C}$ & $F$ & C & $F$ & C & $\mathrm{F}$ & C \\
\hline Fall 1974: & & & & & & & & & & \\
\hline $\begin{array}{l}\text { Basal area }\left(\mathrm{ft}^{2} / \mathrm{acre}\right) \\
\text { Volume }\left(\mathrm{ft}^{3} / \mathrm{acre}\right)\end{array}$ & $\begin{array}{r}36.8 \\
208.6\end{array}$ & $\begin{array}{l}13.3 \\
67.9\end{array}$ & $\begin{array}{r}9.8 \\
51.2\end{array}$ & $\begin{array}{r}4.0 \\
17.9\end{array}$ & $\begin{array}{r}6.9 \\
47.8\end{array}$ & $\begin{array}{r}2.8 \\
12.9\end{array}$ & $\begin{array}{r}7.7 \\
44.2\end{array}$ & $\begin{array}{r}3.0 \\
14.8\end{array}$ & $\begin{array}{r}5.2 \\
28.0\end{array}$ & $\begin{array}{r}3.5 \\
17.8\end{array}$ \\
\hline $\begin{array}{l}\text { Fall 1980: } \\
\text { Basal area }\left(\mathrm{ft}^{2} / \mathrm{acre}\right) \\
\text { Volume }\left(\mathrm{ft}^{3} / \mathrm{acr} \theta\right)\end{array}$ & $\begin{array}{l}118.0 \\
870.1\end{array}$ & $\begin{array}{r}65.5 \\
497.4\end{array}$ & $\begin{array}{r}56.0 \\
402.0\end{array}$ & $\begin{array}{r}34.5 \\
208.0\end{array}$ & $\begin{array}{r}44.0 \\
330.6\end{array}$ & $\begin{array}{r}29.2 \\
207.3\end{array}$ & $\begin{array}{r}40.5 \\
333.4\end{array}$ & $\begin{array}{r}25.9 \\
191.6\end{array}$ & $\begin{array}{r}30.2 \\
240.7\end{array}$ & $\begin{array}{r}25.1 \\
195.9\end{array}$ \\
\hline $\begin{array}{l}\text { Fall 1984: } \\
\text { Basal area }\left(\mathrm{ft}^{2} / \mathrm{acr} \theta\right) \\
\text { Volume }\left(\mathrm{ft}^{3} / \mathrm{acre}\right)\end{array}$ & $\begin{array}{r}169.7 \\
1501.2\end{array}$ & $\begin{array}{l}105.0 \\
835.5\end{array}$ & $\begin{array}{r}94.0 \\
824.4\end{array}$ & $\begin{array}{r}62.3 \\
475.9\end{array}$ & $\begin{array}{r}72.8 \\
646.0\end{array}$ & $\begin{array}{r}57.3 \\
471.1\end{array}$ & $\begin{array}{r}70.4 \\
702.2\end{array}$ & $\begin{array}{r}49.4 \\
385.6\end{array}$ & $\begin{array}{r}55.9 \\
546.4\end{array}$ & $\begin{array}{r}48.1 \\
460.1\end{array}$ \\
\hline
\end{tabular}

\footnotetext{
${ }^{a} \mathrm{~F}$ indicates fertilization; $\mathrm{C}$ is control.
} 
Basal Area and Volume Growth

Discussion
Basal area growth per acre decreased as spacing widened, and basal area increments were greater for the 1981-84 period than the 1975-80 period except for the narrowest spacing (tables 2 and 3 ). The fertilized trees grew more basal area per acre than the controls for all spacing treatments during both periods, but these increases in basal area growth per acre were greater during the first period. Volume growth per acre was also greater for the 1981-84 period for both fertilized and control treatments, and fertilization increased volume growth for both periods (tables 2 and 3 ). Volume growth per acre tended to be greater at narrower spacings (probability of a greater $F$-value in the analysis of variance was 12 percent). By fall 1984, more volume and basal area occurred on fertilized treatments and on narrower spacings (tables 4 and 5).

Consideration of the growth rates only as a function of fertilization and spacing for the 1975-80 and 1981-84 periods shows a definite response to fertilization. Response in succeeding periods after fertilization may result directly from improved tree nutrition and indirectly from altered stocking (Miller and Tarrant 1983). Further, the relative importance of these direct and indirect effects changes with time (Auchmoody 1985, Miller and Tarrant 1983).

One possible way to examine these direct and indirect effects is to use analyses of covariance to examine the periodic annual increments of the fertilized and nonfertilized half plots as a function of tree size or density instead of spacing. In these analyses, height growth is related to initial height, diameter growth is related to initial diameter, basal area growth is related to initial basal area and volume growth is related to initial volume. The term "initial" refers to the value at the start of each period. These analyses of covariance were performed, although they have limited meaning here because the study has so few replications. Therefore the degrees of freedom are so small, that a common slope for all four period-fertilization combinations must be assumed. Results of the analyses of covariance (table 6 ) indicated that periodic annual increments of basal area and volume are related only to the basal area and volume at the start of the period. In other words, the direct effect of fertilization seemed to be finished by the start of the 1975 growing season; the fertilized half plots grew more in basal area and volume after 1975 simply because they had higher basal areas and volumes in 1975. The plotting of the data and the calculating of the regressions for each treatment-period combination (fig. 4, for example) indicated that an assumption of common slopes for each treatment-period combination probably was incorrect. Still, these plots and regressions do imply that basal area and volume growth due to improved tree nutrition was over by 1975 (figs. 4 and 5) even though the last broadcast application of urea was done in fall 1973. These regressions showed little or no difference between fertilized and control half plots for volume growth during the 1981-84 period. For volume growth during $1975-80$ and basal area growth during both periods, there was either no difference between fertilized and control treatments or growth on the control treatments was slightly higher for the same stocking level. According to this implication, the initial increase in tree nutrition resulted in larger trees and higher stocking levels for the fertilized treatments by fall 1974, and the indirect effect of fertilization continued for at least 10 years after the direct effect of increased tree nutrition was over. Unfortunately, no statistical test is available for this design and data that will provide assurance that this implication is true. 
Table 6-Levels of probabllity for significance in the analyses of covarlance for perlodic annual Increments durlng the 1975-80 and 1981-84 perlods

\begin{tabular}{lrccc}
\hline & \multicolumn{4}{c}{ Periodic annual increments } \\
\cline { 2 - 5 } Variables & Height $^{2}$ & Diameter $^{b}$ & Basal area & Volume \\
\hline Spacing & $<0.01$ & 0.02 & 0.33 & 0.63 \\
Period & .75 & .42 & .22 & .26 \\
Spacing $\times$ period & .35 & .31 & .16 & .24 \\
Fertilizer & .57 & .38 & .32 & .37 \\
Fertilizer $\times$ spacing & .10 & .37 & .28 & .28 \\
Fertilizer $\times$ period & .93 & .99 & .84 & .93 \\
Fertilizer $\times$ period $\times$ spacing & .12 & .73 & .39 & .63 \\
\hline
\end{tabular}

a Height is average height.

- Diameter is the quadratic mean diameter. Covariates for each periodic annual increment were the values of average height, diameter, basal area, and volume at the start of each period.

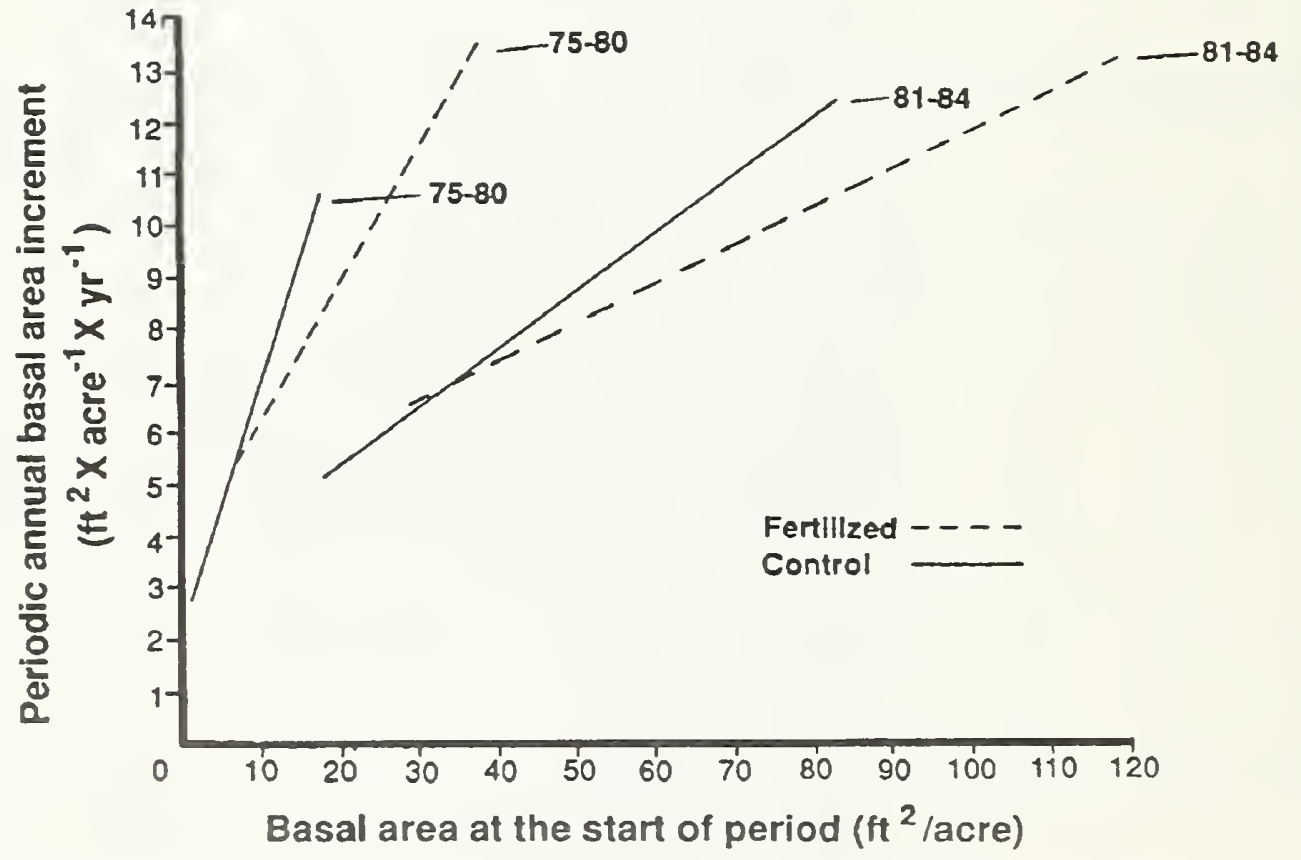

Figure 4-Periodic annual basal area increments for the 1975-80 and 1981-84 growing seasons as a function of basal area at the start of each period. Values of $R^{2}$ are 0.90 or above for each regression. 


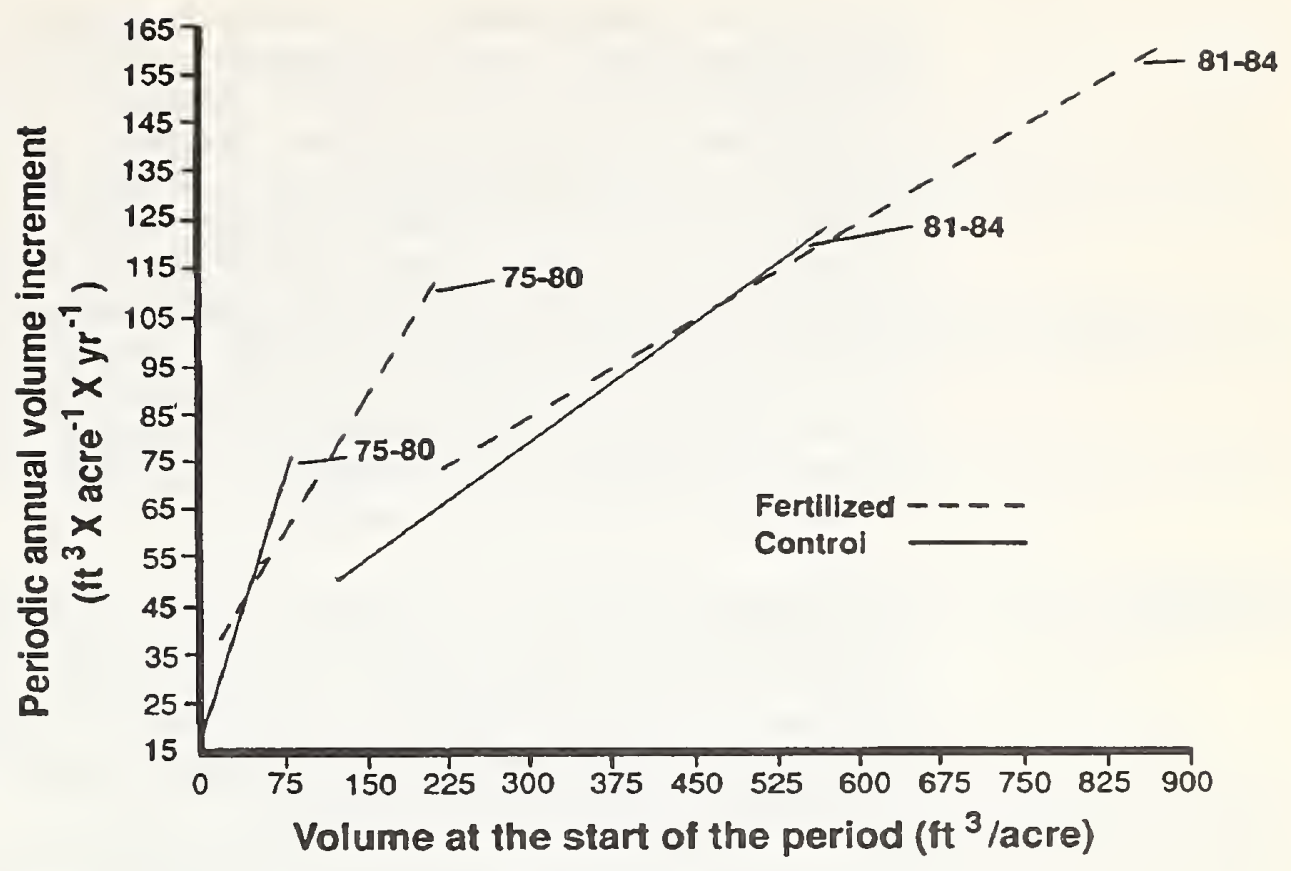

Figure 5-Periodic annual volume increments for the 1975-80 and 1981-84 growing seasons as a function of volume at the start of each period. Values of $R^{2}$ are 0.88 or above for each regression.

Height growth was increased by fertilization at all spacings before additional fertilizer was broadcast over the surface of the fertilizer treatments. As Barrett and Youngberg (1970) report, 3 years after planting the effect of the fertilizer seemed more dramatic belowground than aboveground. Six fertilized and six nonfertilized trees outside the interior study plots were excavated after the third growing season. Granules of fertilizer could still be detected, and about 75 percent of the original fertilizer by weight was recovered. Roots of the fertilized trees were developing readily in the surface horizons but congregated around the fertilizer in the $C$ horizon. The fertilized trees had developed a more extensive root system in the A and AC horizons than the nonfertilized trees, and the fertilized trees had larger multiple tap roots that entered the older buried soil profile and then expanded. Hermann and Petersen (1969) found that ponderosa pine saplings increased growth rates when their roots penetrated through the $\mathrm{C}$ horizons of pumice soils and entered the buried soil. Earlier and more extensive development of the roots of the fertilized trees in the buried profile in this study may have been partly responsible for their increased rate of growth. 


\section{Conclusions}

\section{Literature Cited}

Looking back, it is unfortunate that additional fertilization in fall 1971 and 1973 took place because there is no way to separate the influence of the fertilizer applied at the different times. It is also unfortunate that analyses of covariance cannot be practically employed because of the small number of treatment replications. Regressions of basal area and volume growth as a function of initial basal area and volume for each fertilizer-period combination imply that response of basal area and volume growth due to increased tree nutrition was over one growing season after the last broadcast application of urea. Then, the trees averaged 10 feet high or less. Larger trees on similar sites exhibit a longer direct response period (Powers and others 1988). Placement of fertilizer in the planting hole or near the base of the seedlings may be much more effective than broadcast applications, at least until the trees are larger than saplings. This practice might also increase the competitive advantage of planted seedlings over the surrounding vegetation.

The response to fertilizer had the effect of projecting the plantation forward in time. By the time all of the trees exceeded 4.5 feet in height and the average heights were 7 feet or more (fall 1974), the trees in the fertilized plots were taller and had larger diameters for any given spacing. The larger trees and higher stocking levels for the fertilized half plots for any given spacing then continued to produce more volume and basal area per acre for the next 10 years.

These results suggest that fertilization at the time of planting should be investigated further. Experiments designed to determine the influence of different commercial pellets now available as well as different kinds and amounts of standard commercial fertilizers with and without the influence of competing vegetation need to be initiated. For now, practicing foresters can expect that M.A.P. as used in this study, plus 57 grams of ammonium sulfate in each planting hole will directly increase the growth rates of planted ponderosa pine in the pumice soil region of south-central Oregon for at least six growing seasons and indirectly for much longer where competing vegetation is not a problem.

Atalla, Nabll. 1987. Fertilizer briquets increased first year growth of planted Douglas-fir seedlings in southwestern Oregon. FIR Report. 9(1): 2-3.

Auchmoody, L.R. 1985. Evaluating growth responses to fertilization. Canadian Journal of Forest Research. 15(5): 877-880.

Austin, R.C.; Strand, R.F. 1960. The use of slowly soluable fertilizers in forest planting in the Pacific Northwest. Journal of Forestry. 58(8): 619-627.

Barrett, J.W.; Youngberg, C.T. 1970. Fertilizing planted ponderosa pine on pumice soils. In: Hermann, Richard K., ed. Regeneration of ponderosa pine. Corvallis, OR: Oregon State University Press: 82-88.

DeMars, Donald J.; Barrett, James W. 1987. Ponderosa pine managed yield simulator PPSIM users guide. Gen. Tech. Rep. PNW-GTR-230. Portland, OR: U.S. Department of Agriculture, Forest Service, Pacific Northwest Research Station. 36 p. 
Hass, Ted. 1987. New planted seedlings respond to several fertilizers. FIR Report. $9(1): 3-4$

Herman, Richard K.; Peterson, Roger G. 1969. Root development and height increment of ponderosa pines in pumice soils of central Oregon. Forest Science. 15(3): 226-237

Meyer, Walter H. 1961. Yield of even-aged stands of ponderosa pine. Tech. Bull. 630 (rev.). [Location of publisher unknown]: U.S. Department of Agriculture, Forest Service. $59 \mathrm{p}$.

Miller, R.E.; Tarrant, R.F. 1983. Long-term response of Douglas-fir to ammonium nitrate fertilizer. Forest Science. 29(1): 127-137.

Porada, Hans Joachim. 1987. The effect of aluminum on the growth and mineral composition of Douglas-fir and western hemlock. Seattle, WA: University of Washington. 251 p. Ph.D. thesis.

Powers, Robert F.; Webster, Steve R.; Cochran, P.H. 1988. Estimating the response of ponderosa pine forests to fertilization. In: Schmidt, Wyman C., comp. Proceedings-future forests of the Mountain West: a stand culture symposium; 1986 September 29-October 3; Missoula, MT. Gen. Tech. Rep. INT-243. Ogden, UT: U.S. Department of Agriculture, Forest Service, Intermountain Research Station: 231-233.

SAS Institute. 1982. SAS user's guide: statistics, 1982 ed. Cary, NC: SAS Institute. $584 \mathrm{p}$.

Steel, Robert G.D.; Torrie, James H. 1960. Principles and procedures of statistics. New York: McGraw-Hill Book Co. 481 p.

Volland, Leonard A. 1985. Plant associations of the central Oregon pumice zone. R6-ECOL-104-1982. Portland OR: U.S. Department of Agriculture, Forest Service, Pacific Northwest Region; 1982. 60 p. 

The Forest Service of the U.S. Department of Agriculture is dedicated to the principle of multiple use management of the Nation's forest resources for sustained yields of wood, water, forage, wildlife, and recreation. Through forestry research, cooperation with the States and private forest owners, and management of the National Forests and National Grasslands, it strives - as directed by Congress - to provide increasingly greater service to a growing Nation.

The U.S. Department of Agriculture is an Equal Opportunity Employer. Applicants for all Department programs will be given equal consideration without regard to age, race, color, sex, religion, or national origin.

Pacific Northwest Research Station 319 S.W. Pine St.

P.O. Box 3890

Portland, Oregon 97208-3890 


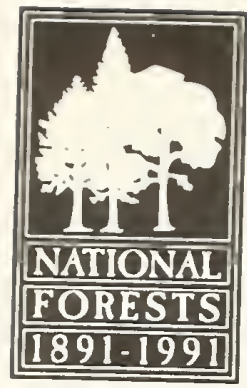

U.S. Department of Agriculture Pacific Northwest Research Station

BULK RATE

POSTAGE +
FEES PAID

P.O. Bcx 3890

Portland, Oregon 97208

USDA-FS

Official Business

Penalty for Private Use, $\$ 300$ 